\title{
Conflict Resolution and Democratisation in the Aftermath of the 2004 Tsunami: A Comparative Study of Aceh and Sri Lanka
}

\author{
Kristian Stokke, Olle Törnquist, Gyda Marås Sindre
}

\section{Introduction}

The earthquake off the west coast of Sumatra on 26 December 2004 unleashed a tsunami in the Indian Ocean that affected more than a dozen countries throughout South and Southeast Asia and stretched as far as the northeastern coast of Africa. The two worst affected areas - North-East Sri Lanka and the Aceh region in Indonesia - have both been marked by protracted intra-state armed conflicts. In the immediate aftermath of the tsunami, international journalists and humanitarian actors argued that the disaster could actually constitute an opportunity for conflict resolution, as the scale and urgency of humanitarian needs should bring the protagonists together in joint efforts for relief, reconstruction and conflict resolution. In contrast, research on the impacts of natural disasters often concludes that disasters tend to deepen rather than resolve conflicts. Four years after the tsunami it can be observed that Aceh and North-East Sri Lanka have followed highly divergent trajectories. In Aceh, a Memorandum of Understanding between the Government of Indonesia and Gerakan Aceh Merdeka (GAM) was signed shortly after the tsunami and has been followed by peace and a process of political integration into Indonesian democracy. In Sri Lanka, the tsunami created a humanitarian pause from the gradual escalation of hostilities and an attempt to create a joint mechanism between the Government of Sri Lanka (GOSL) and the Liberation Tigers of Tamil Eelam (LTTE) for handling humanitarian aid, but Sri Lanka has since then returned to full-scale warfare between the GOSL and LTTE. 
These divergent trajectories suggest that the common denominator - the tsunami disaster - cannot be considered the decisive factor behind the escalation of conflict in Sri Lanka or the conflict resolution process in Aceh, but rather as a critical event that was used by different actors for strategic reasons and generally furthered rather than radically altered pre-existing political processes. This implies that the analytical focus should be on the contextualised political dynamics of conflict and its transformation, rather than a search for a direct causal link between the tsunami disaster and the political outcomes such as war or peace. Our on-going comparative research on the post-tsunami conflict resolution and democratization in Aceh and Sri Lanka addresses these political dynamics through three principal research questions:

1. How and to what extent has reconstruction/development been linked to processes of conflict resolution and rights based democratization?

2. How and to what extent has a process of rights based democratization been related to the parallel processes of reconstruction/development and conflict resolution?

3. How and to what extent have the parallel processes of reconstruction/ development, conflict resolution and democratization generated political transformations of the armed insurgency movements?

This brief article, which is based on work in progress, will highlight some key lessons and preliminary conclusions for each of these research questions.

\section{Linking humanitarian rehabilitation and conflict resolution}

Contemporary armed conflicts are typically intrastate conflicts and concentrated in the poorest countries in the Global South (Kaldor 1999). Such conflicts are often construed, in the foreign policy discourses of the West, as global security threats rooted in underdevelopment, providing a justification for international diplomatic and military intervention in intrastate conflicts, supported by instrumental use of humanitarian and development aid for peacebuilding (Paris 2004, Richmond 2007). This leads Duffield (2001) to the conclusion that security and development have been merged through diplomatic, military and development practices within strategic security complexes in regard to intrastate conflicts in the Global South.

Post-tsunami Aceh and Sri Lanka provide illustrative but divergent examples of this linking of development and peace. Following the enormous losses of lives and livelihoods after the tsunami, UN organisations, aid donor countries and non-governmental organisations organised the world's largest relief and reconstruction operation to date. But the international actors have also facilitated conflict resolution processes in Aceh and Sri Lanka. This has created a situation with parallel and interacting processes of rehabilitation/development and conflict resolution with active participation of a broad range of international actors. 


\section{Linking development and peace in Sri Lanka}

Sri Lanka has, since the anti-Tamil riots in July 1983, been locked in a protracted armed conflict between the Government of Sri Lanka and a militant Tamil nationalist movement demanding self-determination for the Tamil nation and homeland (Tamil Eelam) in North-East Sri Lanka. After the tsunami, political analysts pointed out that practical collaboration around humanitarian relief and rehabilitation could lead to a process of conflict resolution. Early news reporting lent some support to this thesis: the GOSL invited the LTTE to participate in a joint relief task force, the leader of the LTTE extended his condolences to Muslims and Sinhalese in the tsunami-affected areas and many individuals, businesses and organizations provided humanitarian assistance across the dividing lines between the Sinhalese majority and the Tamil and Muslim minorities. Unfortunately, these promising signs of mutual good-will during the first weeks after the disaster were soon replaced by political competition whereby the Government, the LTTE and other political actors used tsunami relief to gain political legitimacy. Recognising these political obstacles to efficient and fair distribution of aid, the international actors demanded that a joint mechanism should be established between the government and the LTTE. An agreement between the GOSL and LTTE to establish a Post-Tsunami Operational Management Structure (P-TOMS) was, however, firmly resisted by the political opposition and when it was finally signed it was put on hold by a Supreme Court ruling that found key elements to be against the constitution of the unitary state. Thus, the opportunity that was created by the tsunami for revitalising the peace process, by way of humanitarian assistance, was missed (Uyangoda 2005b).

The failed attempt to use post-tsunami humanitarian rehabilitation as a step towards peace was reminiscent of the peace process that preceded the tsunami disaster. This attempt at political conflict resolution began shortly after the general elections in December 2001 and included six rounds of peace negotiations between the Government of Sri Lanka (GOSL) and the Liberation Tigers of Tamil Eelam (LTTE) in 2002-2003. The process, which produced a Ceasefire Agreement from 2002 to 2008, revolved around two defining characteristics: (i) crafting of peace through narrowly defined elite negotiations; and (ii) instrumental linking of peace and development through humanitarian assistance and aid conditionalities (Balasingham 2004, Bastian 2007, Goodhand and Klem 2005, Rupesinghe 2006, Shanmugaratnam 2008, Uyangoda and Perera 2003). Both features were closely linked to the internationalization of peace, placing diverse external actors in roles as facilitators of negotiations, ceasefire monitors and aid donors.

The internationalization of peace in Sri Lanka has happened largely through the aid donor/recipient relationship between international donors, the GOSL and LTTE. This linking of peace and development was based on the existence of a mutually hurting stalemate between the protagonists and severe crises of development that brought LTTE and GOSL into negotiations 
and kept them from returning to warfare for some time after the breakdown of negotiations. The GOSL, on the one hand, faced a growing budget crisis with soaring military expenses from the 'war for peace' strategy of President Kumaratunga's government as well as rising costs of living posing serious threats to the legitimacy and electoral survival of the government. The LTTE, on the other hand, faced a humanitarian crisis and an increasingly war-weary Tamil population who had suffered under massive destructions of lives and livelihoods. This situation made both protagonists enter the peace process with a desire to address humanitarian rehabilitation and development needs. The development strategy pursued by the GOSL, led by the right-of-center United National Party, was to further economic liberalisation and capitalise on the assumed peace dividend from reduced military expenses and international aid for post-conflict peacebuilding. The LTTE insisted on the need to address immediate humanitarian needs in the North-East, as this region had been devastated by warfare and bypassed by government development programs. The peace process, with its strong focus on internationally funded humanitarian and development programs, allowed both the GOSL and the LTTE to pursue these strategic interests, thereby presumably also improving their legitimacy among those they claim to represent.

Following from these constellations, the peace process was characterised by an unprecedented sequencing of the negotiation process. The negotiating teams agreed to address immediate humanitarian relief and rehabilitation needs in the war-torn areas and to establish a joint interim mechanism to plan and implement development projects (Rainford and Satkunanathan 2008). These decisions were endorsed by the donors and development aid for humanitarian rehabilitation was distributed to war-affected groups and areas. This was an important contribution towards normalising everyday life in the war zone, but had relatively weak strategic links to the peace process as the delivery of humanitarian aid was largely through international NGOs. The search for a mutually acceptable development administration turned out to be deeply problematic (Shanmugaratnam and Stokke 2008). The LTTE saw an interim administration with a fair degree of autonomy and a guaranteed position for the LTTE as an absolute necessity to ensure the fulfillment of both short-term development needs and long-term demands for internal self-determination. The Sinhalese opposition feared that the interim administration would constitute a first step towards secession and hence saw it as a threat to the sovereignty of the unitary Sri Lankan state. Given the weak government coalition and the mounting opposition from the President and her Sri Lanka Freedom party (SLFP), the Janatha Vimukthi Peramuna (JVP), and other Sinhala nationalist groups, the GOSL was only able to propose minimalist institutional reforms within the framework of the existing constitution. The proposals put forward by the government were rejected by the LTTE on grounds that they were limited in scope and failed to provide for substantive participation of the LTTE in 
decision making and delivery of rehabilitation and development. LTTE's counter proposal for an Interim Self-Governing Authority (ISGA) was, however, seen as a first step towards secession and hence unacceptable to the GOSL. These disagreements between the protagonists over an interim administration for the North-East provided an opportunity for the political opposition to bring the peace process to a halt. In the process, domestic stakeholders also politicised the role of the international actors, who in turn imposed conditionalities in the form of demands for progress towards peace as a prerequisite for further development assistance. This turned out to be an inefficient mechanism as the conditionalities were imposed rather than negotiated with the protagonists to the conflict, were based on vaguely defined and difficult to operationalise criteria and could only be accommodated at a high political cost, especially for the GOSL.

Interestingly, the model for development was generally not subject to discussion, but the LTTE, GOSL and international donors converged around a technocratic delivery of humanitarian aid in war-affected areas and overall normalisation of a neo-liberal development strategy (Bastian 2007, Shanmugaratnam and Stokke 2008). This meant the furthering of the development agenda of the GOSL, but it significantly ran counter to the strong legacy of statism and welfareism in Sri Lanka. The neoliberal development model, which has had a contested presence in Sri Lanka since the late 1970s, has furthered socio-spatial unevenness and deepened the contradiction between the symbolic representation of poor people in political discourse and the material reality of the lower and lower middle classes. These classes are key constituencies for electoral success and commonly constitute a protest vote against the economic policies of the government. In the context of the peace process, political elites that were excluded from government positions and the peace negotiations and electoral constituencies experiencing social and political exclusion, came together in vocal opposition to the peace process, the government and the international actors. This brought down the government at the general elections in 2004 and replaced it with a government combining a militant strategy vis-à-vis the LTTE and symbolic and material concessions to their constituencies in the intermediate Sinhalese classes. This means that while development was used as a forerunner for peace, the chosen model of development furthered social exclusion and thereby undermined the peace process. When this stalled peace process was sought revitalised through the same development-to-peace strategy after the tsunami disaster, the negotiations between GOSL and LTTE again reached a stalemate amidst oppositional politicisation of the issue of interim development administration.

\section{Linking development and peace in Aceh}

The Aceh region has long been a center of resistance, first against Dutch colonial rule and later against various forms of post-colonial 'internal' domination, exploitation and repression. The Indonesian military 
in particular but also local militias and the rebels of Gerakan Aceh Merdeka (GAM) have seriously violated human rights. The post-colonial conflicts emerged under the first President Sukarno, when the demand by Acehnese was for less top-down policies in favor of a combination of more Western oriented federalism and, in the case of Aceh, a stronger role of Islam. As the dominance, exploitation and repression continued, however, under Soeharto's authoritarian capitalist roadmap, the Aceh dissidents opted for radical nationalism and separation. Some space for conflict resolution and democratisation evolved after the overthrow of President Soeharto in 1998. GAM's claim for an independent ethnic state was now supplemented by a new generation of civic movements, primarily among students, who were interested in democratic reformation as in Indonesia at large but felt that this was unrealistic unless Aceh was allowed to opt for independence. Negotiations between the Government and GAM were initiated under the second president after Soeharto, Abdurrahman Wahid. At the same time, independent civic groups gained importance with large numbers of people participating in public protests demanding an end to the conflicts and for democratic change. An agreement on cessation of hostilities was reached in December 2002, but the violence continued and intensified. Meanwhile President Wahid was outmaneuvered and replaced by his more nationalist Vice President Megawati. Her regime turned against the radical decentralization that had been introduced after Suharto and opted for a military solution for Aceh with a state of emergency being declared in May 2003, followed by forceful military offensives.

The current peace process was initiated in 2004 with informal contacts and confidential meetings between Government actors and GAM. These efforts were made possible by the new president Susilo Bambang Yudhoyono and his Vice Jusuf Kalla who were elected in late 2004 but had already tried negotiations as ministers under President Megawati. Partial agreements (including special privileges to some leaders) encountered resistance and skepticism from within the military, Acehnese elites in Jakarta and among exiled GAM leaders (International Crisis Group 2005). Yudhoyono and Kalla's efforts towards negotiated peace gained strength as promises to this effect had clearly contributed to their impressive victory in the direct presidential elections during the second part of 2004. Another crucial issue had been the need to professionalise the military, and retired General Yudhoyno was comparatively resourceful in this regard. Similarly, Kalla had broad support within Suharto's former party Golkar, which now tried to reinvent itself as a moderate and well organised nationalist party beyond any regional and ethnic biases. And while Kalla advocated more business friendly policies, Yudhoyono and Kalla were both committed to decentralisation, though in a more regulated way than during the initial dismantling of Suharto's regime. Taken together, therefore, the new Jakarta government was thus quite well endowed to enter into serious negotiations. More positive attempts to further the process in proper contact with the top level GAM leaders were underway when the 
Tsunami hit and radically transformed the political space and dynamics of conflict resolution. The initial post-tsunami approach to the conflicts and devastation was a de facto combination of (a) negotiations between the Indonesian government and GAM facilitated by international actors, and (b) relief and reconstruction in co-operation between the international humanitarian- and development aid communities, the central government and the military. The linking of these two processes was only informal and not planned, yet crucial. Furthermore, the co-ordination between the various donors and Indonesian parties in the relief and reconstruction was initially quite minimal and the situation was at times next to chaotic. The international community has primarily been involved in post-tsunami relief and reconstruction efforts. Indirectly however, the international presence was decisive in also keeping dominant actors such as the military and big business at bay. Meanwhile the Helsinki talks continued on the basis of two major principles: First, that there would be no partial agreements (aside from voluntary ceasefires) until a comprehensive agreement had been reached; second, that the issue of independence for Aceh would be set aside in favor of 'self-government', where the major issues aside from arranging the ending of the hostilities, dissolving GAM's armed forces and demilitarising the presence of the Indonesian government, were to agree on a basic division of responsibilities between the central and local government and design institutions for full human and democratic rights for everyone to make the self government real. A peace agreement between the Indonesian Government and GAM was signed in August 2005, setting the stage for a complex process of reconstruction of tsunami-affected areas, demobilisation and reintegration of GAM guerrilla forces and local democratisation in Aceh. The relief and reconstruction work was mainly in the hard hit costal areas, where the presence of GAM armed units was thin. This means that it was never a viable proposition to try to negotiate peace by giving primacy to development. Yet, it does not mean that humanitarian and development efforts are not affected by partisan economic, political and other interests. In Aceh sections of the international community and the central government have been able to negotiate some rules and regulations, but problems of distribution, corruption and abuse of power are hard to counter without strong and democratic civil and political societies. Meanwhile the initial phases of new peace negotiations were confined to the government and GAM, ignoring other parties to the conflict. These excluded parties include hawkish nationalist politicians and officers but also those having demonstrated the most sincere interest in peace and democracy, namely the long repressed and civic groups and movements that were crucial before the collapse of the previous peace negotiations. Towards the end of the Helsinki negotiations, however, crucial informal discussions were facilitated between the GAM negotiators and leading actors in civil society. Moreover, the agreement in Helsinki was only on a broad framework for how discussions and further agreements would be negotiated within a new and regular democratic process where all actors would be granted equal opportunities. 


\section{Comparing Sri Lanka and Aceh}

These brief accounts point to the linking of reconstruction/ development and conflict resolution in both Aceh and North-East Sri Lanka, while also indicating that development has played a more prominent role in the Sri Lankan peace process than in Aceh. Humanitarian assistance has, in the former case, been used as a precursor to conflict resolution. In Aceh, humanitarian aid has been limited to a more conventional role of postconflict peacebuilding and demobilization of insurgents, but aid has not been used as a precursor and substitute for conflict resolution. The main explanation for this divergence is to be found in the power constellations between and within the governments and the insurgency movements, defining the space and scope for conflict resolution and democratization. While the weakness of the government coalition precluded substantive conflict resolution in Sri Lanka, there existed a political space for conflict resolution in Aceh that was widened and strategically utilised by both the government and GAM after the tsunami disaster.

\section{Rights based democratization}

In the context of 'new wars' and international peace promotion, a hegemonic conception of liberal peace has evolved around the thesis that liberal democracy is more likely to yield peaceful change between and within states than alternative models of government (Richmond 2007). Based on the understanding that economic underdevelopment combined with unaccountable government constitute a fertile ground for armed insurgency, there is a strong emphasis on establishing virtuous cycles of neoliberal development, liberal democracy and liberal peace (Collier et al 2003, Paris 2004). Given recent experiences with internationally facilitated transitions to liberal democracy and structural adjustments to neoliberal globalization, it is assumed that liberal peace can be crafted through internationally facilitated elite negotiations supported by instrumental and conditional use of humanitarian and development aid (Bastian and Luckham 2003). Actual experiences with transitions to peace and democracy, however, call this assumption into question as recent transitions have typically produced formal rather than substantive rights-based democracies and many peace processes have failed to go from 'negative peace' (i.e. absence of warfare) created by ceasefire agreements to lasting and substantive conflict transformation (Harriss, Stokke and Törnquist 2004, Uyangoda 2005a). These experiences highlight the needs for alternative conceptions and strategies for more substantive peace based on rights-based democratization. While structural and institutional factors are crucial and vary, of course, with different contexts which we can not elaborate on in this article, Nordic experiences with social democratic politics point to the importance to some core elements of such alternative politics irrespective of the specific constraints. These political elements include class alliances and broad political coalitions in favour of dynamic economic growth that can be combined with and even benefit from 
political and civil rights ensuring political equality as well as democratic institutions providing means for political representation, accountability, and regulation of market economies, in addition to popular capacity to utilise and expand these spaces for democratic control of public affairs based on political equality.

\section{Democratization in Sri Lanka}

The contemporary Sri Lankan political system can, at the risk of oversimplification, be described in general terms as a majoritarian formal democracy within a unitary and centralised state, with extensive concentration of power and few de facto constitutional and institutional checks on the powers of the executive government. Since Independence in 1948, the stakes in the field of politics - in terms of political power, economic resources and social status - have become exceedingly high. This has given rise to political fragmentation and intense intra-elite rivalry, yielding instrumental constitutional reforms, populist politicisation of ethnicity, strategic coalitions and crossovers as well as political corruption and patronage. As the dynamics of this political field have been decisive in the making and continuation of conflicts in post-colonial Sri Lanka, political transformation are crucial to the achievement of lasting peace (Uyangoda 2005a).

These political constellations have important implications for the design and dynamics of peace processes. A recurrent pattern has been that Government peace initiatives have been challenged by the political opposition, mobilising majoritarian Sinhalese nationalism against proposals that grant substantive minority rights and devolution of power. In this environment of political fragmentation and ethnic outbidding, the coalition that comes to power seeks to depoliticise Tamil nationalism without making extensive concessions to the Tamil demands for nationhood and self-determination. For instance, Sri Lanka's 4th peace process (1994-1995) sought to depoliticise Tamil separatist nationalism through decentralization to all provinces without granting any special status to the North-East, thereby preserving the integrity of the unitary state. The 5 th peace process sought to bring the North-East into 'normal development' under the assumption that this would transform Tamil separatism into a demand for autonomy that could be accommodated within the existing constitution.

The $5^{\text {th }}$ peace process was shaped by the existence of a crisis of governance in the sense that the government was based on a weak coalition with only a small majority in the Parliament. This created a situation where the GOSL had limited prospects for conflict resolution through constitutional reforms and had to search for strategies of conflict management and resolution within limits set by the existing constitution. What ensued were narrowly defined peace negotiations, both in terms of actors and issues. The peace process included narrowly defined track one' negotiations between the warring parties in the conflict without any parallel process among other stakeholders. This meant that the political 
opposition, including the left-of-center Sri Lankan Freedom Party and the left ethnonationalist Janatha Vimukthi Peramuna (JVP), the Muslim minority and the broad diversity of civil society organizations including the Buddhist Sangha, were all excluded from the peace negotiations. The content of the negotiations were also narrowly defined to questions of geographic arrangements for power sharing between LTTE and the GOSL in interim institutions for development administration, postponing questions of devolution of power, human rights, governance reforms and substantive rights-based democratization. This means that the political questions of human rights and political representation, which were behind the making and perpetuation of the conflict, remained largely unaddressed.

At the time of the peace process, Sri Lanka was characterised by a de facto dual state structure, with parallel but very different problems of democratic deficits within two political entities. On the one hand was the Sri Lankan state formation, which can be described as a consolidated electoral democracy, but is also characterised by majoritarianism within a unitary and centralised constitution and illiberal political practices that include ethnic constitution of demos, elitist incorporation of people and ethnic outbidding (de Votta 2004). On the other hand was the emerging state formation within LTTE-controlled areas, where LTTE has demonstrated an ability to govern but doing so by way of authoritarian centralisation with few mechanisms for democratic representation (Stokke 2006). This points to a dual need for political transformations towards rights-based democratisation, but this turned out to be too complicated and contentious to be handled in the peace process. The strong focus on humanitarian needs in the peace process and the strong statist orientation of the LTTE provided a basis for a technocratic control over economic affairs in North-East Sri Lanka, but without any functional institutions for democratic control. In short, the Sri Lankan peace process was characterised by a primacy of development over politics, using humanitarian rehabilitation and development as a trust-building and presumably depoliticising precursor to political conflict resolution, but very little attention to institutional reforms to ensure substantive democratization (Shanmugaratnam and Stokke 2008).

\section{Democratisation in Aceh}

Peace in Aceh was, in contrast to Sri Lanka, achieved through peace negotiations that focused on core political questions of devolution of power and democratic reforms. This mode of conflict resolution was greatly facilitated by the fact that it was possible to take advantage of democratic openings within the Indonesian state and to expand on these political spaces. The peace process did not simply focus on the question of autonomy and a rewarding treaty for rebel leaders, but human rights and democratic self government to all, including the civil activists and victims of both the conflict and the tsunami.

While the peace process was conditioned by the relatively weak position of GAM and the fact that the newly elected president and vice 
president were both interested and quite resourceful in negotiating peace, there were a number of additional factors that gave the process its democratic character. First, nationalism in Aceh was indeed ethnic but more rooted in a territorially defined political project than based on separate ethnic and religious community-organising. Second, GAM's strategy of not winning militarily but causing trouble while waiting for Indonesia to crumble was undermined by the decentralised and semi-democratic system in other parts of the archipelago that prevented balkanization. Third, the old GAM guard in Stockholm was less able to transform this from a drawback to an asset than the younger and civic partners. These partners developed their own contacts with pro-democrats outside Aceh, especially when in exile under Megawati's military campaign. Fourth, GAM refused Indonesian vice president Kalla's strategy of granting profitable secret deals for its own leaders, opting instead for comparatively open negotiations by adopting and briefing civic partners and insisting on a truce that would grant equal rights to all residents in future politics and implementation. Fifth, the Finnish facilitator Martti Ahtisaari blocked negotiations on 'impossible problems', focusing instead on basic issues of decommissioning, sharing of natural resources and most importantly on political institutions to handle other issues through 'self-rule'. Sixth, this in turn enabled the democratic side of GAM to develop extensive political proposals for democratic self-rule with local political parties and independent candidates; proposals which the Government did not refuse. Seventh, when later on divisions developed in GAM over decision-making and participation, the critics and their civic partners could mobilise their grass roots by advocating internal democracy and launching independent candidates (rather than compromising with Jakarta-based parties) in the December 2006 elections, thus scoring landslide victories.

Regarding economic development, there were specific conditions that facilitated an orientation towards rights-based democratization. At the time of the tsunami disaster in 2004, Aceh was relatively unaffected by the reformasi in other parts of the country and continued to suffer from militarised corruption and local money politics. After the tsunami, therefore, most experts agreed that donors, technocrats and NGOs with funds and civic institutions had to be allowed to act autonomously to minimise 'normal' Indonesian abuse and corruption. This did limit much of the expected corruption and military subordination of people - which in turn gave democracy a chance. These measures to protect against private appropriation of public resources combined with the introduction of democratic rights and institutions and the capacity of GAM and democracyoriented civil society actors to use and promote the new political institutions created a potential for social democratic rather than just liberal peace.

What is the current state of democracy in Aceh and what are the prospects for realising the potential of rights-based democratization? A recently concluded assessment of democracy in Aceh yields seven main conclusions (Törnquist 2008). The first conclusion is about the rise of 'a 
political demos'. While Aceh remains far from a citizen based demos, it is clear that the people and activists have turned remarkably quickly from the sufferings, frustrations and distrust of civil war and natural disaster to engage in politics and to refute the common argument that local political freedoms would spur the abuse of ethnic and religious identities and sustained separatism. The second main point is that politics is at the helm of Aceh, even businessmen spend most of their energy within polity related spheres. The military seem to have lost ground and the huge economic reconstruction and development activities are largely separated from organised politics. The third conclusion is that the successful introduction of liberal democracy with free elections and a number of liberties is not accompanied with a similarly outstanding improvement in political representation. The fourth argument is that while there is a tendency among actors to avoid parties and turn directly to various institutions of governance, there are insufficient democratic institutions and capacities to frame the practices. This is primarily to the benefit of people with 'good contacts'. It will undermine the democratic space and the actors that have given priority to democracy rather than power-politics. The fifth conclusion is that the liberal democratic transformation has not yet been accompanied with sufficiently matching efforts towards real legal justice, rule of law and accountable and transparent governance, not even by foreign donors and their Indonesian counterparts who use to emphasise these drawbacks. The sixth conclusion is that several of the problems seem to be particularly serious where the gubernatorial IRNA ticket was successful and even more clearly where the district candidates supported by KPA and SIRA won - but that there are no sign of higher democratic political capacity to alter the situation. The final conclusion is that most of the problems that have been identified seem to be particularly difficult to fight for the pro-democratic actors that have been so crucial in Aceh while others find it easier to adjust to 'normal' Indonesian standards and practices. The remarkable achievements in Aceh are not on the brink but the foundations are shaky and the prognosis is poor if the actors in the peace process that pointed to the chances of developing and making use of the emerging Indonesian democracy are getting undermined.

In conclusion, it was possible to promote peace by taking advantage of the democratic openings and to expand on them. Likewise it should be possible right now to also introduce measures towards good governance of further development. The major difference is that in the immediate post-tsunami period it was sufficient that the experts, donors and NGOs insulated relief and reconstruction from dominant politics and 'business as usual'. In the current situation they also need to support the shaping of alternative democratic channels. Democratic channels to enable people themselves to abstain from personal patronage and voicing instead their own needs, while also keeping politicians, bureaucrats and businessmen accountable. In short, there is no need to 'sequence democracy' - 'only' to pave the way for gradual improvements by developing democratic instruments and popular capacities to advance and use them. 


\section{Comparing Sri Lanka and Aceh}

Some key observations can be made about conflict resolution and political transformations in Aceh and North-East Sri Lanka. Regarding conflict resolution it should be noted that the Aceh and Sri Lanka peace processes followed two different paths. The Sri Lankan peace process follows a peculiar sequencing, seeking to fulfill the immediate demands for reconstruction and development as a means to promote political negotiations about core issues and a solution to the conflict. The Aceh peace process applied an institutional/political approach by attempting to push forward specific agreements before making a final peace pact between the protagonists. The aim was to implement institutional and constitutional changes as part of the current national reforms of decentralising political power from the center to the regions, aiming at establishing a more accountable government at the local level. Importantly, as already indicated the negotiation tactics in both Aceh and Sri Lanka were confined to the power-holding elites and high ranking rebel commanders, while generally excluding popular forces ("civil society", non-combatants, ordinary people) from the negotiation processes. Aside from contacts on the sidelines between GAM negotiators and sympathetic civil society organizations, the major exception in Aceh was the extensive democratic involvement of various actors in the immediate implementation of the peace treaty, including in the drafting of the new law on governing the province. This has important implications for the prospects and dynamics of broad political transformations through rights-based democratization. While Sri Lanka has an important legacy of social democratic economic regulation and social welfare that has given way to economic liberalization in combination with a strong and centralised state, Indonesia has recently undergone a transition from authoritarian rule to liberal democracy and an associated turn to economic liberalism. While the conflicts are produced within these national political contexts, the war-affected areas of NorthEast Sri Lanka and Aceh have to some extent been bypassed by the turn to neoliberal development, providing a basis for a certain technocratic economic regulation in the context of peace processes.

\section{Political transformation of armed insurgency movements}

Contemporary academic debates about transitions from armed conflicts to peace revolve around notions of 'conflict resolution' and 'conflict transformation' (Miall, Ramsbotham and Woodhouse 2002). Scholars within the conflict transformation approach acknowledge the centrality of elimination of conflict through negotiations and peace agreements, but argue that conflict resolution often focus too narrowly on elitist and formal peace processes, calling instead for attention to the broad and long-term transformation of grievances, forces and strategies. This implies that the process of building a lasting peace is much wider than formal negotiations between the protagonists to the conflict. Nevertheless, conflict resolution and conflict transformation are closely linked processes, since "Resolution 
of a conflict requires a fundamental transformation of the structure as well as the dynamics of the conflict. Similarly, action towards resolution constitutes transformative politics and praxis" (Uyangoda 2005a, p. 14). This means that a peace agreement may provide a necessary but not sufficient condition for sustainable peace. The challenge is to substantiate, in theory and practice, the mutual constitution of conflict resolution and conflict transformation.

A key question in this context regards the relationship between institutional change in favor of democratization and devolution of power, and changing political practices, especially within armed insurgency movements. Luckham, Goetz and Kaldor (2003) examine this link between formal political arrangements and practical politics in conflict-torn societies, and observe that institutional arrangements affect the range of possible political practices, but not in a straightforward manner. For instance, the establishment of democratic institutions does not automatically yield political transformations towards democratic politics. In fact, many of the recent democratic transitions have yielded a coexistence of democratic institutions and nondemocratic politics. While institutional arrangements may not determine political practices, Luckham et al also point out that institutional reforms open up the political space for democratic politics and may transform political practices and actors in a democratic direction. The latter possibility is especially relevant, but generally under-researched, for armed insurgency movements (de Zeeuw 2008). In an attempt to address this research gap, we suggest close attention to the role of changing opportunity structures and the manner in which insurgency movements understand and act in regard to their political spaces.

\section{Political transformation of LTTE}

The question of political transformation of the LTTE, which is a well-organised and resourceful militant movement that has paid relatively little attention to political work, must be placed in the context of the dynamics in the peace process. The war between LTTE and the GOSL reached a mutually hurting stalemate in the late 1990s, following a series of military victories for the LTTE that brought extensive areas under their control and created a certain military parity of status with the GOSL. Whereas the GOSL was put on the defensive by the battlefield dynamics, the LTTE also appeared to have reached a limit for what they could achieve without unleashing negative international sanctions, especially from the Government of India (Uyangoda 2005a). This balance of power brought the protagonists into negotiations and kept them from resuming warfare, despite the breakdown of the negotiation process, until the balance was altered through military preparations by the protagonists and changing positions among the international actors. The Ceasefire Agreement on 22 February 2002 froze this military-territorial balance of power and segmented a de facto dual state structure (Shanmugaratnam 2008). In this context, the LTTE followed a strategy of institutionalising power sharing 
by building separate state institutions within the areas under their control and thereby producing a pretext for internal or external self-determination based on earned sovereignty (Stokke 2006, 2007). In this sense, LTTE utilised the 'no war/no peace' situation created by the CFA to pursue their strategic interests, making the peace process an extension of war by other means.

The 'development-to-peace' strategy of the 5th peace process allowed the GOSL and the LTTE to discuss an interim development administration in North-East Sri Lanka and also agree, in principle, to explore a federal solution to the conflict. This represented a major transformation on both sides. On the LTTE side, it marked a shift from their earlier struggle for a separate state to a demand for self-government within a federal state. On the government side, it marked a shift from the earlier insistence on conflict resolution within the framework of the unitary state, to a willingness to discuss power sharing between two political units within a federal state. This discursive shift towards a federal solution to the conflict held the prospect of further transformations of both majority and minority politics, but the peace process stalled before the core political issues where addressed, thereby effectively precluding substantive political transformations. It can, nevertheless, be observed that the 2002 Ceasefire Agreement yielded a partial and conditional shift in LTTE's struggle for self-determination from militant to political means, with the political wing emerging in a coordinating role in regard to both the peace process and building of local LTTE-controlled state-like institutions. There was no attempt to build a political party, but the LTTE facilitated the Tamil National Alliance (TNA) during the 2004 parliamentary elections and held regular consultations with TNA MPs.

The construction of parallel state-like institutions within areas under LTTE-control represented a growth in administrative capacity rather than an acceptance of political pluralism and human rights. The dominant form of governance embedded in the LTTE state institutions is that of a strong and centralised state with few formal institutions for democratic representation, but there were also elements of partnership arrangements and institutional experiments in the fields of social welfare and economic development (Stokke 2006). While the resumption of warfare put a full stop to these nascent political transformations of LTTE, the experiences from the 'no war/no peace' situation under the Ceasefire Agreement demonstrate that the LTTE may hold a certain potential for political transformation if there are conducive changes in their political opportunity structures.

\section{Political transformation of GAM}

In Aceh's local elections of December 2006, GAM cleared the table of more than fifty percent of the positions as district heads, including the position of governor. Although having failed to unite into one political party at the time, former GAM rebels had proven to the world that they could claim legitimacy amongst the Acehnese. This political transformation of 
GAM from a small, but persistent guerilla movement at its inception in 1976, to a significant civilian political force in the local elections in 2006, must be seen against the backdrop of broader process of democratization in Indonesia following the fall of Suharto in 1998. Arguably, from the late 1990s and until the 2006 elections, GAM transformed along two crucial, but interlinked dimensions: (i) as a hegemonic movement ingrained through patrimonial ties across the province, and (ii) as a broader reform movement emphasising democracy and human rights. Importantly, these two processes of transformation were facilitated by very different mobilising structures and political opportunity structures and have resulted in quite distinct shifts in terms of ideology, structure, and power basis.

The transformation into a rebel movement with a reform agenda occurred in tandem with an increased focus on human rights and democracy in Indonesia in general. GAMs initial political strategy and ideational foundation was rooted in classical ethno-nationalist notions of independence for the Acehnese people and was first and foremost characterised by the upholding of its military pressure against the Indonesian state, its infrastructure and security forces by the means of guerilla warfare. Towards the end of the 1990s, the brutal repression of Suharto's New Order regime, the increased focus on human rights abuses and demands for democratization amongst civilian political forces inside Aceh and beyond were integrated into GAMs overall political program and added to GAMs overall expression and overall legitimacy. Military brutality against civilians in Aceh during periods of heavy military crackdown, popularly known as DOM, naturally became a key source form which GAM could mobilise support. Furthermore, within the limited framework of the New Order state, GAM was about the only viable voice of opposition. This shift in ideological positioning within the exiled GAM-leadership in Sweden and amongst the significant diaspora located in Malaysia opened the space for increased inclusion and alliance building across broader sectors of Acehnese society which accelerated with the demise of the New Order regime. Hence, the principal political opportunity structure which facilitated the general and specific politics of civilian based nationalism in Aceh was the combination of forces between the two major political voices in Aceh: GAM and the democracy and human rights movement organised under the umbrella banner of SIRA.

At this point, GAMs strategy changed from running an internal war along the terms of ethno-nationalist struggles to internationalise the conflict. Central figures in GAMs leadership travelled to the UN and later to the EU to spread the word of severe human rights abuses by the Indonesian military inside Aceh. The efforts at internationalising the conflict along these lines were also driven forward by central figures in the democracy movement organised under the banner of SIRA.

GAMs strategy of political shift was not identical with giving up the demands for independence and the overall political struggle, but did indeed bring about shifts in the legitimacy basis of the movement and 
served to deradicalise significant sections of the leadership in the face of several rounds of negotiations initiated in the period from 1999 to 2004 .

The political changes in Jakarta are particularly significant in understanding the transformations of the overall conflict structures in Aceh. The decentralization reforms implemented at the national level at various stages since 1999 also radically changed the political opportunities of militant nationalism in Aceh. Resolving the conflict in Aceh became one of Jakarta's key priorities with the implementation of special autonomy law (NAD) in 1999, later replaced by the far more comprehensive Nagroe Aceh Darussalam (NAD) law in 2001 initially aimed to create an attractive alternative to secession by granting Aceh as wide ranging powers of self governance as possible within the unitary state (Miller 2004, 2006). At this stage GAM felt self-assured by the popular support for a referendum and not only rejected autonomy, but also actively sought to undermine its implementation. A key problem was that the NAD law was not anchored in any common agreement between the two parties, and did not make any concessions to GAM. Parallel to the institutional arrangement, a peace process was initiated in late 1999 in Geneva which produced two significant turning points; the mid-2001 humanitarian pause brought to a standstill in 2001 and a more substantial cessation of hostilities agreement (COHA) in December 2002.

These processes corresponded to significant changes in the local fabric of dominance inside Aceh. The period of peace negotiation were accompanied with a shift in the internal positioning of GAM also inside Aceh. Parallel to the alliance building amongst a moderate section of the GAM leadership, in particular amongst the exiled activists and leadership, GAM struggled to maintain, secure, and expand their power bases within Aceh (Sindre 2008). As such, in terms of opportunity structures which facilitated the widening of already existing patrimonial structures and the terms of GAMs political economy, the weakening of the Indonesian state in Aceh in 1998-1999 had provided not only a basis for mobilization, but also a basis for military expansion into the remaining sub-districts of Aceh (Schultze 2004). As the political situation in Jakarta was increasingly unstable, a power vacuum in Aceh's provinces enabled GAM to resurface as a military force and widen their military and civilian representation across Aceh. Attempts at establishing civilian state structures were made, and although GAM was never able to control large areas of land, their expansion secured an opportunity to become ingrained in the local social fabric beyond the traditional strongholds previously limited to the areas along the northern coast of the province.

By 2001 then GAM was stronger both militarily, in numbers, and more self-secure in terms of popular support than it had been in a very long time, although still a rather small guerilla movement in comparison to the likes of the LTTE. By 2002, the Indonesian military had gathered force after the presidential shift to Megawati Sukarnoputri and responded to increased GAM activities and its expansion with their own mix of strategies 
which mostly included attacking and killing GAM personnel (Aspinall 2006, Kingsbury and McCulloch 2006). The recourse to violence, accusations against GAM commanders in the field, and general dissatisfaction amongst human rights activists inside and outside the province, served to focus attention to new ways of solving the conflict. The year 2003 was the grimmest and most dispiriting period in Aceh's recent history. The peace process had stalled, GAM had weakened militarily, and central figures inside SIRA had been forced into exile. Still, by 2004, GAM had developed on two fronts: into a more moderate direction amongst the exiled leadership in alliance with strong forces in SIRA at the same time as strengthening the internal power bases of individual commanders whom had had the opportunity to make use of already existing patrimonial networks inside Aceh.

By 2004, then facilitated by the presidential shift in Jakarta to a new and more moderate leadership in SBY and Kalla, in face of a major humanitarian disaster following the tsunami, both sides were willing to enter into significant compromises. In terms of conflict resolution and peace, the transformation of GAM facilitated by the shifting governance structures in Jakarta and direct focus on democracy and human rights instead of ethno-nationalism as the basis for mobilization, into more reform minded political movement has been significant. At the same time, the more locally ingrained, rurally based commanders who developed their military and social powerbases inside Aceh in the period 1999-2001 and continued to fight their ideological battle for independence in the jungle, have felt increasingly sidelined by the more moderate alliance of GAM and SIRA since the signing of the MoU. This section represents a more dispiriting transformation away from a more substantial democratization, especially in face of the significant internal splits which have surfaced as mobilization for the 2009 elections have started.

\section{Comparing Sri Lanka and Aceh}

These brief accounts point to the substantive political transformation of GAM and the aborted transformation of LTTE. The decisive factors behind these divergent experiences are to be found in the dialectical relationship between changing opportunity structures and the capacity and willingness of key actors within the insurgency movement to make use of such political spaces. Whereas the ceasefire agreement in Sri Lanka allowed LTTE to pursue a strategy of institutionalising de facto power sharing with the GOSL, the peace process was too restricted and the militancy of LTTE too entrenched to foster a substantive political transformation towards a democracy-oriented political movement. In Aceh, in the context of transitions from authoritarianism with warfare and emergency rule in Aceh to peace and liberal democracy, GAM has undergone a political transformation into a reform movement emphasising democracy and human rights. While changing political opportunities are of critical importance, the divergent cases of LTTE and GAM also draw attention to the character of the insurgency movement in terms of their aims, means and organizational structures. 


\section{Conclusion}

This article is based on work in progress and the findings are tentative rather than conclusive. At the most general level our preliminary comparative analysis of conflict resolution and democratization in Aceh and Sri Lanka shifts the attention, from a focus on the 2004 tsunami disaster as an external shock that could make or break transitions to peace to a focus on the contextualised political dynamics and the tsunami as an important event that was used by different actors to pursue their agenda in regard to peace, democracy and development. A key finding is that transitions to peace and democracy are shaped and, at times undermined, by the constellations and strategies of elite and popular political forces.

Beyond this general conclusion, our analysis highlights three key dimensions that have set Aceh and Sri Lanka on different trajectories in regard to conflict transformation. First, we conclude that both cases have been marked by close links between reconstruction/development and conflict resolution, but we also find that there are critical differences in the sense that development has been used as precursor and substitute for political conflict resolution in Sri Lanka but not in Aceh. Second, we observe that the manner in which core political issues are handled have been very different in Aceh and Sri Lanka. While national political changes enabled a political integration of Aceh into Indonesian democracy, the Sri Lankan process postponed core issues of democracy, human rights, devolution of power and good governance to unspecified future negotiations. This has created promising prospects for rights-based democratization in Aceh, but much more restricted possibilities in North-East Sri Lanka. Third, we also observe that these different experiences regarding changing political spaces for peaceful change and the different characteristics of the insurgency movements have produced very limited and conditional changes within LTTE in Sri Lanka while there has been a much more substantive transformation of GAM in Aceh. 


\section{References}

Aspinall, E 2006, The Helsinki Agreement: A more promising basis for peace in Aceh? Policy Studies 20, The East-West Center, Washington D.C.

Balasingham, A 2004, War and peace. Armed struggle and peace efforts of liberation tigers, Mitcham, Fairmax, UK.

Bastian, S 2007, The politics of foreign aid in Sri Lanka: promoting markets and supporting peace, Sri Lanka, International Centre for Ethnic Studies, Colombo.

Bastian, S and R. Luckham (eds.) 2003, Can democracy be designed? The politics of institutional choice in conflict-torn societies, Zed, London.

Collier, P., V. L. Elliott, H. Hegre, A. Hoeffler, M. Reynal-Querol and N. Sambanis 2003, Breaking the conflict trap: civil war and development policy, Oxford University Press, Oxford.

De Votta, N 2004, Blowback. Linguistic nationalism, institutional decay, and ethnic conflict in Sri Lanka, Stanford University Press, California.

de Zeeuw, J (ed.) 2008, From soldiers to politicians: transforming rebel movements after civil war, Lynne Rienner, Boulder, CO.

Duffield, M 2001, Global governance and the new wars: the merging of development and security, Zed, London.

Goodhand, J. and B. Klem 2005, Aid, conflict and peacebuilding in Sri Lanka, The Asia Foundation, Colombo.

Harriss, J., K. Stokke and O. Törnquist (eds.) 2004, Politicising democracy: the new local politics of democratisation, Palgrave Macmillan, New York.

International Crisis Group 2005, Aceh: a new chance for peace, Asia Briefing no. 40, International Crisis Group, Jakarta/Brussels.

Kaldor, M 1999, New and old wars: organised violence in a global era, Polity Press, Cambridge.

Kingsbury, D. and L. McCulloch 2006, 'Military business in Aceh', in A Reid (ed.), Verandah of violence: the background to the Aceh problem, Singapore University Press, Singapore.

Luckham, R., A.M. Goetz and M. Kaldor, M 2003, 'Democratic institutions and democratic politics', In S Bastian and R Luckham (eds), Can democracy be designed? The politics of institutional choice in conflict-torn societies, London, Zed.

Miller, M.A 2004, 'The Nanggroe Aceh Darussalam law: a serious response to acehnese separatism?', Asian Ethnicity, vol. 5, no.3.

Miller, M.A 2006, 'What's special about apecial autonomy in Aceh?' , in A Reid (ed.), Verandah of violence: the background to the Aceh problem, Singapore University Press, Singapore.

Paris, R 2004, At war's end: building peace after civil conflict, Cambridge University Press, Cambridge.

Rainford, C. and A. Satkunanathan 2008, Mistaking politics for governance. The Politics of interim arrangements in Sri Lanka, International Center for Ethnic Studies, Colombo. 
Ramsbotham, O., T. Woodhouse and H. Miall 2005, Contemporary conflict resolution $2^{\text {nd }}$ ed, Polity Press, Cambridge.

Richmond, O.P 2007, The transformation of peace, Palgrave Macmillan, New York.

Rupesinghe, K 2006, Negotiating peace in Sri Lanka: efforts, failures and lessons (Volume I and II), The Foundation for Co-Existence, Colombo.

Schulte-Nordholt, H 2004, 'Decentralisation in Indonesia: less state, more democracy?', in J.Harriss, K. Stokke and O. Törnquist (eds), Politicising democracy: the new local politics of democratisation, Palgrave Macmillan, Houndmills.

Schulze, K.E 2004, The Free Aceh Movement (GAM): anatomy of a separatist organization, The East-West Center, Washington D.C.

Shanmugaratnam, N (ed.) 2008, Between war and peace in Sudan and Sri Lanka: deprivation and livelihood revival, James Currey, Oxford.

Shanmugaratnam, N. and K. Stokke 2008, 'Development as a precursor to conflict resolution: a critical review of the fifth peace process in Sri Lanka', in Nadarajah Shanmugaratnam (ed.), Between war and peace in Sudan and Sri Lanka: deprivation and livelihood revival, James Currey, Oxford.

Sidel, J.T 2004, 'Bossis and democracy in the Philippines, Thailand and Indonesia: towards an alternative framework for the study of 'local strongmen', in J. Harriss, K. Stokke and O. Törnquist (eds), Politicising democracy: the new local politics of democratisation, Palgrave Macmillan, Houndmills.

Sindre, G.M 2008, 'From separatism to political inclusion; the political transformation of the Free Aceh Movement (GAM)', in O. Törnquist, Stanley and T. Birks (eds.), Aceh: the role of democracy for peace and reconstruction, PCD Press, Jogjakarta.

Stokke, K 2006, 'Building The Tamil Eelam State: Emerging state nstitutions and forms of governance in LTTE-controlled Areas in Sri Lanka', Third World Quarterly, vol. 27, no. 6, pp. 1021-1040.

Stokke, K2007, 'War by other means: the LTTE's strategy of institutionalising power sharing in the context of transition from war to peace', Third World Quarterly, vol. 28, no. 6, pp. 1197-1201.

Törnquist, O 2008, 'Aceh's democracy. Diagnosis and prognosis', in O. Törnquist, Stanley and T. Birks (eds.), Aceh: the role of democracy for peace and reconstruction,PCD Press, Jogjakarta.

Uyangoda, J (ed.) 2005, Conflict, conflict resolution and peace building, Department of Political Science and Public Policy, University of Colombo, Colombo.

Uyangoda, J. and Perera, M (eds.) 2003, Sri Lanka's peace process 2002. Critical perspectives, Social Scientists' Association, Colombo. 
